\title{
The Educational and Globalization Components of Sustainable Development, and Their Factors
}

\author{
Olga Borisova $^{1}$, Victoria Frolova ${ }^{1, *}$, and Larisa Artamonova ${ }^{2}$ \\ ${ }^{1}$ Financial University under the Government of the Russian Federation, 12599349 \\ Leningradsky Prospekt, Moscow, Russia \\ ${ }^{2}$ Institute of Economics and Crisis Management, 117312 53/2 Vavilova Street, Moscow, \\ Russia
}

\begin{abstract}
The strategic task of the world community is to create a global network of environmental education, in which all educational systems include acquaintance with environmental problems faced by humanity, and form an understanding of the interconnection of man, society and nature on a global scale. The article is devoted to the study of basic provisions and current trends in the formation of innovative processes of globalization of education, in particular, environmental education. Environmental education can be defined as the process of acquiring knowledge of environmental problems, the reasons for their occurrence, the need and the possibilities for their solution. Understood in this way, it should contribute to the formation of environmental awareness and to the development of ecological culture as integral components of the concept of environmental policy aimed at preserving the environment. It has been established that globalization processes in education are universal, they are not inherently essential to the industry-specific training of specialists. Digital transformation, international governmental and institutional agreements, competition relations are the main drivers for the development of environmental education.
\end{abstract}

\section{Introduction}

Modern challenges of transforming globalization processes against the background of the integration of digital processes in all spheres of financial, economic and human relations require the development of innovative approaches to building a model of education in universities. Educational organizations are provided with a wide range of development of self-determination, but meanwhile, the existence in a single information and communication space leads to the need to respect basic principles, international agreements, technical capabilities and rules of social behavior. The study of transformation processes and their determining factors, in order to identify the most significant and promising ones, is one of the urgent tasks of the development of education globalization.

Today in Russia, the process of education is changing radically. This trend is not avoided by colleges, technical schools and universities, providing training in environmental

\footnotetext{
*Corresponding author: academy@,fa.ru
} 
education. The globalization of education has the most significant effect on the change in the training process. The UNDP in Human Development Report (1999) presents globalization as an increasing interdependence between the inhabitants of the earth at the economic, technological, cultural and political levels. Globalization is a general trend that leads not only to the liberalization of trade, the release of goods and services to the world market, but also, in fact, the abolition of national borders. In part, it is associated with the development of technology, in particular the Internet. The speed of data transmission grows, the cost of information processing decreases, all this leads to the possibility of eliminating distances that were previously not surmountable and allowed the formation of a national space. Today, categories of time and space are not taken into account due to significant changes associated with the introduction of new production technologies, the use of electronics, information technology, etc.

Due to changes, consumption patterns, values and standardized cultural products are changing. The behavior of people and their relationships become more similar, with the result that national differences disappear. This trend is observed around the world.

\section{Materials and Methods}

The theoretical basis of the study is the work of Russian authors. Ababkova M.Yu. [1] observes the issues of globalization and internationalization of education, Kamashev SV, Kosenko T.S. [2] emphasize the current state of globalization processes in the educational sphere, N. Tikhomirova. [3] studies on the role of universities and teachers in the system of global education, Ashilova MS and Nalyvayko N.V. [4] study the global challenges of our time and their impact on global education, Dianova N.F. [5] considers the main implications of globalization for universities and teachers. This area of research is widely covered in the works of foreign authors. In particular, S. Bakhtiari [6] identifies the challenges facing the education system and the emerging opportunities. S. Mitra [7] studies the issues of self-organized learning and proves the possibility of its use in practice, L. Jackson [8] observes the main aspects of globalization that influence the process of education. There are joint studies, for example, Litinskaya A., Katazhina Ch. [9], showing the features of the globalization of education in Poland. However, these works do not pay due attention to the study of the impact of the globalization of education on industryspecific higher education institutions, and the transformation of their environmental education is not shown.

\section{Results and Discussion}

The process of globalization of environmental education implies fundamental changes in the national educational system and the world order, and the loss of value by national borders [1]. Of particular importance in the transformation of these processes is the digitalization of all processes, including educational ones.

The goals of global environmental education are:

- actualization of the conditions of human existence and the norms of his ecologically responsible behavior of society;

- identification of effective methods and technologies for the selection of knowledge transfer in terms of the use of modern environment technologies;

- transition to a new phase of the elimination of ecological illiteracy, associated with the formation of an understanding of the new facts of environmental problems;

- development of measures to increase interest in environmental education by young people; 
- formation of a system of continuous education, allowing for the training of personnel to carry out activities in the face of uncertainty.

These goals should be divided in two categories: implementable at the state level and implementable by educational institutions. The special attention should be paid to the second goal when starting the development strategy for educational institutions in the industry. In the context of the development of globalization processes, we should not forget about websites - the "calling card" of the universities. It should be noted that by 2015, websites were created in almost $100 \%$ of universities (Fig. 1 [10]).

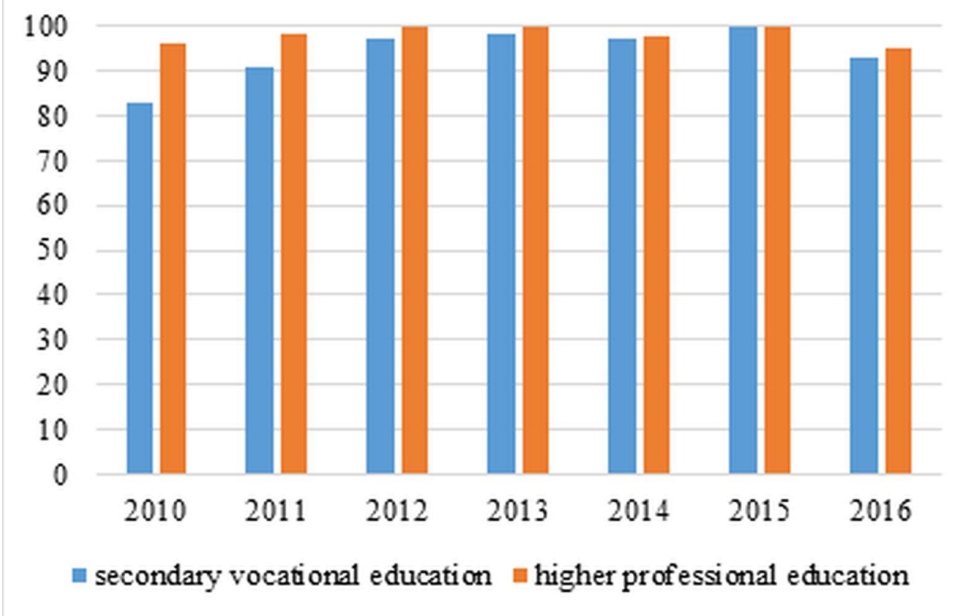

Fig. 1. Share of educational institutions with a website on the Internet in the total number of independent educational institutions, per cent.

The website of the university is not only advertising and informational in nature, which helps in attracting students, but is also a multifunctional platform that expands the scope for receiving and transmitting information. The site becomes a means of additional communication between various structural units of the university, teachers, students, the main information base of internal and external users, moreover, the content of the site is one of the criteria for making a decision on the accreditation of the university.

Some researchers emphasize that global education is not only a set of national educational spaces and systems, in the first place, it acts as a special megasystem that sets and implements the goals of national and world educational policy. This system is aimed at empowering the development of personality [6]. Consequently, today educational institutions that train students in secondary vocational and higher education programs in the field of subsoil use should monitor technology and methods of training specialists in similar areas abroad and find foreign partners to implement joint training projects.

Such an approach will allow the exchange of pedagogical knowledge and projects [4]. As part of this direction, new skills will be acquired and unique intellectual assets will be developed that are necessary to improve the industry. As a result, this will lead to the emergence and upbringing of a "new synthesis" of national and world values of education. At the same time, it is necessary to estimate the danger of damage to national values in education, social injustice in the field of education due to cultural, ethical and linguistic differences that will be formed as a result of the exchange.

Today, as a result of the increasing interdependence and mutual influence of the spheres of the economy, a single global market has been formed. This led to the appearance of the following: 
- transnational production, which forms fundamentally new requirements for the skill level of employees. Under these requirements, the quality of vocational education should also vary. As a result, there is a need for the formation of international educational standards;

- the economy of global knowledge, which will eventually lead to the internationalization of universities and their training programs.

- transnational education, in which universities are being consolidated with the aim of winning a share of the global educational market, increasing the mobility of education.

These trends lead to the development of general strategies and principles of higher education, a set of educational programs is being formed, the main task of which is the additional environmental training of students for their future professions. In addition, it is expected that the knowledge and skills that are in demand on the labor market in any country of the world will be developed [1]. The educational model in such conditions takes into account the logic of globalization and is considered as a factor of production that has an impact on environment, as well as on the possibility of attracting funds, developing competition and creating jobs.

In this direction, special attention should be paid to increasing the mobility of staff of educational institutions that train students in the field of subsoil use and environment regulation. This will allow the exchange of experience with leading scientists of the world and get ideas of the most advanced technologies in the industry. The implementation of this direction is possible when using the Internet, which will allow employees not to leave their workplace in an educational institution.

In a society, the difference in the level of financial possibilities becomes more acute. Among current trends, one can observe the process of marketization of education, associated with investments by large businesses and international financial institutions, in standardization and the dissemination of training modules for employees in accordance with technological requirements. At the same time, programs are being implemented related to the elimination of basic ecological illiteracy as a means of environment protection. At the same time, the transition to the concept of education, expressed in the self-learning of personnel, is being positioned. For this, an infrastructure is created that includes the resources used by the person for self-study. With this model of learning, self-organizing communities will arise. They will include people who want to receive and impart knowledge. Within these communities, relevant issues will be discussed with the interested audience. Such interaction will be organized using information technologies that will facilitate the search for potential partners. The disciplines realized in the higher education institutions which are carrying out training of specialists in the field of subsoil use and ecology in the majority belong to the difficult ones, having a technical orientation. However, according to some authors, this is not an obstacle to the transition to a new concept of education. So Mitra S. argues that people can independently study the most complex material, they are ready for self-organization and can share their knowledge with others. The main problem lies in the development of an infrastructure model that would allow them to realize their capabilities most effectively, as well as in the level of motivation. If the problem can be solved, the number of teachers can be significantly reduced, and the costs of traditional education are optimized.

Universities are given the opportunity to independently choose a model of education. However, the realities of the global education market are like these: despite the consolidation of universities, their number is decreasing (see Table 1), while the competition between universities is increasing, as well as demand for the quality of training, primarily due to the development of digital technologies to improve the educational process and take it beyond the territorial boundaries of universities. At present, the sphere of subsoil use is served by 45 universities (Table 1 [10]). 
Table 1. Dynamics of the number of educational institutions in Russia.

\begin{tabular}{|c|c|c|c|c|c|c|}
\hline Indicators & $\mathbf{1 9 9 1}$ & $\mathbf{2 0 0 0}$ & $\mathbf{2 0 1 0}$ & $\mathbf{2 0 1 4}$ & $\mathbf{2 0 1 7}$ & $\mathbf{2 0 1 7 / 2 0 1 0}$ \\
\hline $\begin{array}{c}\text { The number of } \\
\text { universities }\end{array}$ & 519 & 965 & 1115 & 938 & 662 & $-40.6 \%$ \\
\hline
\end{tabular}

In addition, competition among universities in Russia is triggered by a factor in the deterioration of the demographic situation, as well as the departure of applicants to secondary vocational education, largely from the reluctance to take the USE. Between 2010 and 2017, the number of graduates of the 11 th grade decreased by $23.5 \%$ (see Table 2 [10]).

Table 2. The dynamics of the number of applicants, in terms of graduates of 11 classes.

\begin{tabular}{|l|c|c|c|c|c|c|c|c|c|}
\hline Indicators & $\mathbf{2 0 1 0}$ & $\mathbf{2 0 1 1}$ & $\mathbf{2 0 1 2}$ & $\mathbf{2 0 1 3}$ & $\mathbf{2 0 1 4}$ & $\mathbf{2 0 1 5}$ & $\mathbf{2 0 1 6}$ & $\mathbf{2 0 1 7}$ & $\mathbf{2 0 1 7 / 2 0 1 0}$ \\
\hline $\begin{array}{c}\text { Number of } \\
\text { graduates }\end{array}$ & 803.5 & 737.7 & 732.1 & 708.5 & 665 & 622.4 & 641.6 & 614.7 & $-23.5 \%$ \\
\hline
\end{tabular}

In an effort to practice-oriented training, in order to attract students to universities through employment, higher education institutions begin to actively interact with the business.

The Bologna process has a significant impact on the globalization of educational processes. The main directions of it relate to the development of joint diplomas as a means of achieving the goals of the Bologna Declaration. They are also related to the fact that their creation contributes to the development of quality assurance systems, recognition, enhanced transparency and consistency of higher education systems throughout Europe, as well as the development of academic mobility of students and teachers. It stimulates academic and student mobility, including through the use of cyberspace, supported by information and communication technologies.

As a result of all the above mentioned changes, e-learning is becoming one of the priority areas at the universities. The implementation of e-learning determines the need to create open educational resources, the development of e-pedagogy approaches that allows you to make education accessible and flexible.

In particular, one of the areas of manifestation of the processes of globalization in education is the remote technologies for the implementation of basic educational programs. As can be seen from Figure 2, distance education is increasingly covering various areas of study, both in higher and secondary vocational education. The maximum share is $80 \%$ of higher education organizations was covered in 2015. At the same time, it should be noted that the share of such organizations in the field of secondary vocational education is steadily growing (Fig. 2 [10]). 


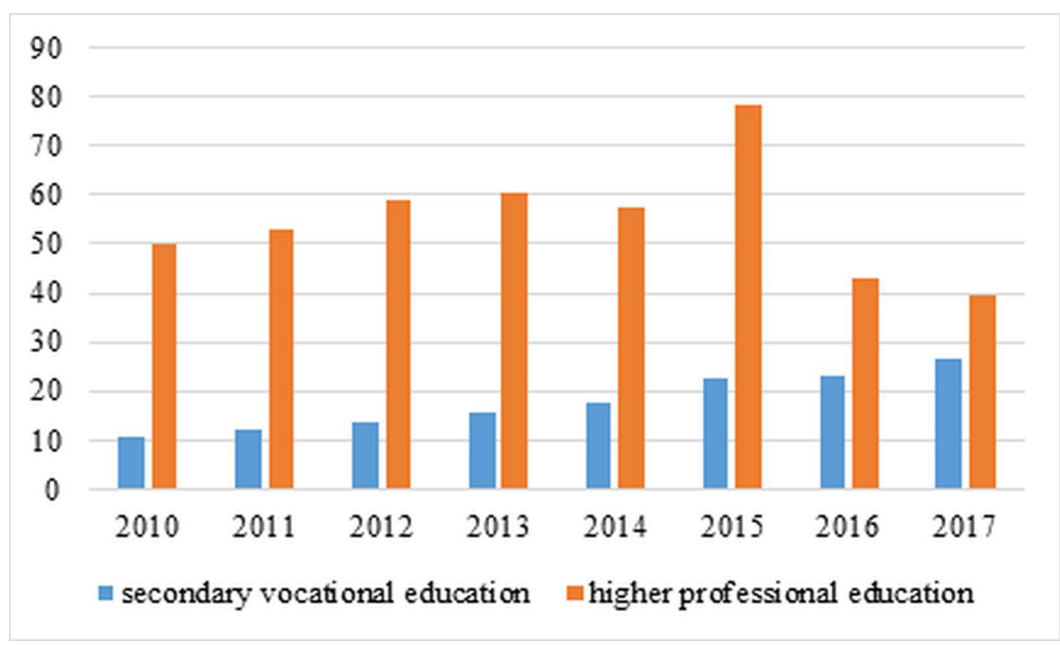

Fig. 2. Share of educational institutions implementing educational programs using distance learning technologies in the total number of independent educational institutions, per cent.

At the same time, the problems associated with the globalization of the education process have an impact on the content side of majors and, as a consequence, on the quality of training. Recently, alternative learning platforms and student certification have been actively emerging [11]. For example, the Coursera platform [12] offers online training from the best universities and companies in the world.

The development of globalization processes is facilitated by academic mobility programs, within which it is planned to transfer someone related to education for a certain (usually up to a year) period to another educational institution (in their own country or abroad) for learning, teaching or research [13-15]. In particular, leading Russian universities implement the "two diplomas", "inclusive education" programs, research internships and short-term mobility programs.

This study allowed the authors to conclude that, against the background of innovation in the university, there is a significant transformation of the requirements imposed on a specialist in a modern university. This person must be able to adapt in modern society, be intellectual and moral, have critical and creative thinking and develop it constantly, work well with information, be competent and competitive in the market.

\section{Conclusion}

Performed research in the area of educational and globalization components of sustainable development allowed coming to the following conclusions:

1. The development of globalization, primarily in the field of education, is impossible without the development of the Internet space, which allows people with disabilities to be included in this process.

2. The development of the globalization process is hampered by a number of factors, the main ones being the uneven coverage of the territories with a mobile communication network and the Internet.

3. Requirements for the training of specialists, bachelors and masters are aimed at maximizing the requirements of professional competencies, taking into account the basic provisions of the Bologna Agreement, which allows training in double degree programs. 
4. Thanks to the processes of globalization, information-communicative national borders are eliminated.

5. The globalization of education is accompanied by active changes in the business models of education.

6. Innovation direction in education, first of all, is online education.

7. The processes of globalization of education are observed in secondary vocational, higher and postgraduate education.

8. It is important not to lose environmental and ecological components of the educational process.

9. The globalization of education leads to increased competition among universities.

10. Current requirements of higher education are becoming more and more oriented towards sustainable development and its specifics in the domestic and international market.

\section{References}

1. M.Yu. Ababkova, Theory and practice of service: economics, social sphere, technology, 1:7, 46-51 (2011)

2. S.V. Kamashev, T.S. Kosenko, Philosophy of education, 6:45, 124-132 (2012)

3. N.V. Tikhomirova, Economics, statistics and informatics, 3, 3-7 (2014)

4. M.S. Ashilova, N.V. Nalyvayko, Philosophy of education, 1:58, 26-37 (2015)

5. N.F. Dianova, Modern educational technology in the global educational space, 7, 13-19 (2016)

6. S. Bakhtiari, Globalization and Education: Challenges and Opportunities (BITGA, London, 2010)

7. S. Mitra, Beyond the Hole in the Wall: discover the Power of Self-Organized Learning (LLC New York, 2012)

8. L. Jackson, Globalization and Education (Oxford Research, Oxford, 2015)

9. A. Litinskaya, Ch. Katazhina, Veles, 6:36, 57-61 (2016)

10. Higher education institutions of Russia engaged in the training of specialists (specialist) for the needs of subsoil use (MISIS, Moscow, 2016)

11. O. Borisova, V. Frolova, E. Merzlikina, E3S Web Conf., 21, 04016. (2017).

12. O. Kalenov, S Kukushkin, E3S Web Conf., 41, 04025 (2018)

13. O. Kalenov, E. Shavina, E3S Web Conf., 41, 04054 (2018)

14. V. Frolova, O. Dolina, T. Shpil'kina, E3S Web Conf., 21, 04018 (2017)

15. E. Dotsenko E., N. Ezdina. E3S Web Conf., 41, 04048 (2018) 